\title{
Studying the Relationship between Factors related to Stress and Stress Management of Insurance Employees of Iran Social Security Organization
}

\section{Estudiar la relación entre los factores relacionados con el estrés y la gestión del estrés de los empleados de seguros de la Organiza- ción de Seguridad Social de Irán}

\author{
Reza Shojaeian \\ Islamic Azad University, Kerman, Iran. \\ ORCID: https://orcid.org/0000-0003-0360-3985 \\ Saeed Sayadi" \\ Islamic Azad University, Kerman, Iran. \\ ORCID: https://orcid.org/0000-0003-2917-9043 \\ Farzaneh Bigzadeh Abbasi \\ Islamic Azad University, Kerman, Iran. \\ ORCID: https://orcid.org/0000-0002-4119-1523 \\ Hamdollah Manzari Tavakoli \\ Islamic Azad University, Kerman, Iran. \\ ORCID: https://orcid.org/0000-0001-8616-5743
}

Received 06-14-20 Revised 08-10-20 Accepted 09-01-20 On line 09-30-20

*Correspondence

Email: sayadi@iauk.ac.ir
Cite as:

\footnotetext{
Shojaeian, R., Sayadi, S., Bigzadeh Abbasi, F., \& Manzari Tavakoli H., (2020). Studying the Relationship between Factors related to Stress and Stress Management of Insurance Employees of Iran Social Security Organization. Propósitos y Representaciones, 8 (SPE3), e770. Doi: http://dx.doi.org/10.20511/pyr2020.v8nSPE3.770
} 


\section{Summary}

Introduction \& Purpose: Considering the stressors in the Social Security Organization and the management of these factors in order to improve efficiency and quality of medical services, the present study aimed to to provide a stress management model for insurance employees of the Social Security Organization of Iran. Materials and Methods: This research is applied in purpose and is survey in method. The statistical population consisted of three groups: Experts familiar with the field of employee stress management that by selective non-random sampling method, 15 individuals were selected. Results: All employees and managers of the Social Security Organization of Iran that 462 were selected based on the Cochran's formula, and 232 people were selected by stratified random sampling method appropriate to the size of the population. In this study, a questionnaire was used to collect the required data. The model design and approval questionnaire with 29 components and indicators was changed to 24 items after obtaining the opinion of experts using the Delphi method. The Stress-Related Factors Questionnaire included 72 questions and the Stress Management Questionnaire consisted of 24 questions. In this study, the content validity of the questionnaire of factors related to stress and stress management were 0.915 and 0.921 respectively, and their reliability was calculated to be 99.1 and 94.6 , which was greater than 0.7 and it was acceptable. Data analysis was performed using structural equation modeling with Lisrel software. Discussion: At $5 \%$ level error between individual factors (-0.33), occupational factors (-0.37), managerial factors (-5.99), organizational factors (-4.62), environmental factors $(0.760)$, there was a significant and inverse relationship between stress and stress management of insurance employees of the Social Security Organization of Iran. Conclusion: The existing facts in the discussion of psychopathology and mental health in the workplace show that a significant percentage of the causes of mental illness and work fatigue among the employees of organizations can be found in the behavior methods and personality of managers.

Keywords: Management, Stress, Employees, Iran Social Security Organization

\section{Resumen}

Introducción y propósito: Teniendo en cuenta los factores estresantes en la Organización de la Seguridad Social y la gestión de estos factores con el fin de mejorar la eficiencia y la calidad de los servicios médicos, el presente estudio tuvo como objetivo proporcionar un modelo de gestión del estrés para los empleados de seguros de la Organización de la Seguridad Social de Irán. . Materiales y métodos: Esta investigación se aplica con un propósito y es una encuesta en el método. La población estadística estuvo conformada por tres grupos: Expertos familiarizados con el campo del manejo del estrés de los empleados que por método de muestreo selectivo no aleatorio, se seleccionaron 15 individuos. Resultados: Todos los empleados y gerentes de la Organización de Seguridad Social de Irán que fueron seleccionados 462 con base en la fórmula de Cochran, y 232 personas fueron seleccionadas por el método de muestreo aleatorio estratificado apropiado al tamaño de la población. En este estudio, se utilizó un cuestionario para recopilar los datos requeridos. El cuestionario de diseño y aprobación del modelo con 29 componentes e indicadores se cambió a 24 ítems después de obtener la opinión de expertos mediante el método Delphi. El Cuestionario de factores relacionados con el estrés incluía 72 preguntas y el Cuestionario de manejo del estrés constaba de 24 preguntas. En este estudio, la validez de contenido del cuestionario de factores relacionados con el estrés y el manejo del estrés fue 0,915 y 0,921 respectivamente, y su fiabilidad se calculó en 99,1 y 94,6, que fue mayor que 0,7 y fue aceptable. El análisis de datos se realizó mediante el modelado de ecuaciones estructurales con el software Lisrel. Discusión: Al 5\% de error de nivel entre factores individuales (-0.33), factores ocupacionales (-0.37), factores gerenciales (-5.99), factores organizacionales (-4.62), factores ambientales (0.76), hubo una relación significativa e inversa entre el estrés y la gestión del estrés de los empleados de seguros de la Organización de la Seguridad Social de Irán. Conclusión: Los hechos existentes en la discusión de psicopatología y salud mental en el lugar de trabajo muestran que un porcentaje significativo de las causas de 
enfermedad mental y fatiga laboral entre los empleados de las organizaciones se puede encontrar en los métodos de comportamiento y personalidad de los gerentes.

Palabras clave: Gestión, Estrés, Empleados, Organización de Seguridad Social de Irán.

\section{Introduction}

Stress is one of the main problems of human beings for centuries. However, it seems that with the advancement of technology, not only the amount of psychosocial-social pressures has not decreased, but also its amount and intensity has increased. What has caused to consider this disorder in the recent years is its devastating impact on human life, work, interpersonal relationships and other personal and social situations. The workplace and job stress can cause mental illness in employees or accelerate the development of mental illness. Following work experience, a person suffers from mental illness becomes disabled and incapacitated, which can create many challenges for both the individual and the community, and most importantly the organization in which people work (Ranjbar \& Mantegh, 2018).

According to the studies, a high percentage of employees in organizations have examined the signs that indicate the presence of stress in them. According to one of the studies, reducing the issues and problems that lead to employee stress in the workplace is mainly at the disposal of the organization's management, so examining the amount of stress caused by factors and problems in the workplace can always inform the management about the Physically and mentally health of its employees so that if there are negative signs of stress, the necessary decisions can be made to reduce this destructive factor and the organizational space can be led without stress and can be reached to its highest level of productivity (Maier et al., 2013).

In fact, the 21 st century can be called the century of stress and psychological pressures. Undoubtedly, moving towards achieving organizational goals and achieving those goals and ultimately the development of society depends on increasing the performance of employees in organizations, and stress has the most important effect on individual performance, thus when stress exceeds a certain limit, it reduces the performance of the individual and since in the workplace, managers are considered as one of the most important elements of the organization, they also face various psychological pressures whose effects on the stress of employees are undeniable (Qarakhani \& Zafaranchi, 2018).

Therefore, the amount of stress at a balanced level will be associated with the best performance, and if the amount is more or less than a range, the performance will be decreased. If the stress continues for a long time, the person will gradually get tired and the continuation of this situation will cause a decrease in the physical and emotional energy and of the person and his ability, because the person's ability is one of the basic elements in increasing productivity and productivity is also a function of the ability and knowing the job as well as organizational support (Nguyen, 2015). Considering that people at least spend one third of their lives in the workplace and many of their social relationships are formed during working hours and all people in the workplace feel some degree of stress, so (Llopis \& Foss, 2016) states that stress at work is actually due to the accumulation of stressors and work-related situations that people are working with them and will be effective on the person's performance in the whole organization (Llopis \& Foss, 2016).

(Imani \& Mokhtari, 2018) states that job stress in the workplace can have detrimental effects on the physical and mental health of employees and the amount of stress at a balanced level will bring the best performance and if the amount is more or less than a range the performance will decrease. 
If the stress continues for a long time, the person will gradually get tired and the continuation of this situation will cause a decrease in his physical and emotional energy and his ability, because the person's ability is one of the basic elements in increasing productivity and productivity is also a function of the ability and knowledge of the job as well as organizational support, so the performance of individuals in the organization will decline, which explains the need to pay attention to stress in the workplace (Talebi, 2018). One of the sectors in which the role and destructive effect of employee stress is much more prominent is the Social Security Organization. Because the employees of the Social Security Organization, especially the employees of the insurance department of this organization, who are faced with a large number of clients and a large workload and given that a wide range of the target population of the Social Security Organization are pensioners and retirees (Afshani et al., 2017), therefore, considering the stressors factors in the Social Security Organization and management of these factors in order to improve the efficiency and the quality of health services seems necessary and can help the performance of the health system to meet the challenges. Therefore, it is important to pay special attention to stress management of insurance employees of the Social Security Organization of Iran so that in the next few years, with the support and efficiency of this organization, we will see the promotion of health and insurance services as well as the development of social security system in the country (Zamanian \& Pakdel, 2015). Thus, the problem of the present study is that is there a significant relationship between the components of stress and stress management of insurance employees of the Social Security Organization of Iran? What is the model of stress management of insurance employees of the Social Security Organization of Iran?

\section{Materials and Methods}

This research is applied in terms of purpose, and is survey in terms of method and is correlational descriptive research in nature. The statistical population consists of three groups: 1) Experts familiar with the field of stress management of employees, whose number is unknown and are distributed throughout the country and their selection is selective and should have characteristics such as knowledge and experience in the subject, tendency, have enough time to participate and have effective communication skills (Maier et al., 2013), have scientific research and articles related to the research topic, availability, experience, suitability of the field of study, doctoral degree and teaching at the university. Using selective non-random sampling method, 15 people were selected. 2) All employees of the Social Security Organization of Iran, whose number is 2067, and to determine and select the sample size based on the paired data method, i.e. for each manager two employees under the control of the same manager was considered and 464 people were selected by stratified random sampling method appropriate to the size of the population. 3) Managers of the Social Security Organization of Iran (582 people) who are working in 33 general departments of social security in 31 provinces and according to Cochran's formula, 232 of them were selected by stratified random sampling method appropriate to the size of the community. In this study, in order to collect the required data, three questionnaires have been used. 1. The model design and approval questionnaire which is consisted of 29 components and indicators of factors related to stress, which after obtaining the opinion of experts with Delphi method, the number of items in this questionnaire was changed to 24 items. The scoring of the questions is set in the form of a 5-point Likert scale from perfectly suitable to completely inappropriate; 1. Questionnaire for determining the factors related to stress in the Social Security Organization of Iran, which was answered by the insurance staff of this organization and consists of 72 five-choice questions. 3. Stress Management Questionnaire that has been answered by the managers of this organization and consists of 24 five-option questions.

The questionnaires of the present study were first reviewed and approved by 15 experts in terms of face and conceptual validity, and then for measuring the content validity, the CVR method and content validity were used. The formula of this method is as follows: 


$$
C V R=\frac{n_{e^{-}} \frac{N}{2}}{\frac{N}{2}}
$$

Where $\mathrm{N}$ represents the total number of responding experts, $\mathrm{n}_{\mathrm{e}}$ is the number of experts who have approved the item. The CVR value can be calculated for all indicators and factors. The CVR value can be varied between -1 and +1 . When CVR $=0.00$, it means that only $50 \%$ of the respondents considered the subject appropriate. Therefore, if CVR value is closer to one, more respondents have identified the subjects appropriate. In this study, the validity of the Stress-Related Factors Questionnaire was calculated to be 0.915 , and the validity of the Stress Management Questionnaire was calculated to be 0.921 . According to the calculations, the reliability of the questionnaire (factors related to stress) using Cronbach's alpha is equal to $99.1 \%$ and the reliability of the questionnaire (stress management) is equal to94.6\% which are acceptable (greater than 0.7). Data analysis was performed using structural equation modeling using LISREL software.

\section{Results}

\section{Identifying and Screening Employees Stress Factors}

Based on previous studies, research literature and interviews, a total of 24 indicators of factors related to employee stress were identified. In the first stage of the Delphi method, these criteria were studied by the field experts and these experts were asked to submit a suggestion if they have a proposal on the combination of some criteria in a new criterion, and finally no index was added to these sub-criteria. A description of the indicators employee stress factors can be seen in (Table 1):

In the second step of Delphi method, first, 24 indicators of factors related to employee stress are screened to select the criteria that are more important and appropriate. Then, by the field experts who were 15 people in the selected sample and were familiar with all subindicators, according to the Delphi method, each criterion was examined based on the purpose. Delphi method was used for the initial screening of the identified criteria (Table 2).

\section{Table 1.}

Summary of Indicators of Employees' Stress Factors

\begin{tabular}{|c|c|c|}
\hline Main structure & Components & Subcomponents \\
\hline \multirow{11}{*}{$\begin{array}{l}\text { Factors related to } \\
\text { employee's stress }\end{array}$} & \multirow{4}{*}{$\begin{array}{l}\text { Individual } \\
\text { factors }\end{array}$} & Difficulties in using capabilities \\
\hline & & Lack of opportunity to learn new skills \\
\hline & & Conflict between work and family \\
\hline & & Conflict in individual goals \\
\hline & \multirow[t]{4}{*}{ Job factors } & Nature of the job \\
\hline & & Ambiguity and conflict between roles \\
\hline & & High-volume or low-volume role and method of work \\
\hline & & Job harassment \\
\hline & \multirow{3}{*}{$\begin{array}{l}\text { Management } \\
\text { factors }\end{array}$} & Management power \\
\hline & & Personality and management style \\
\hline & & Management planning and organization \\
\hline
\end{tabular}




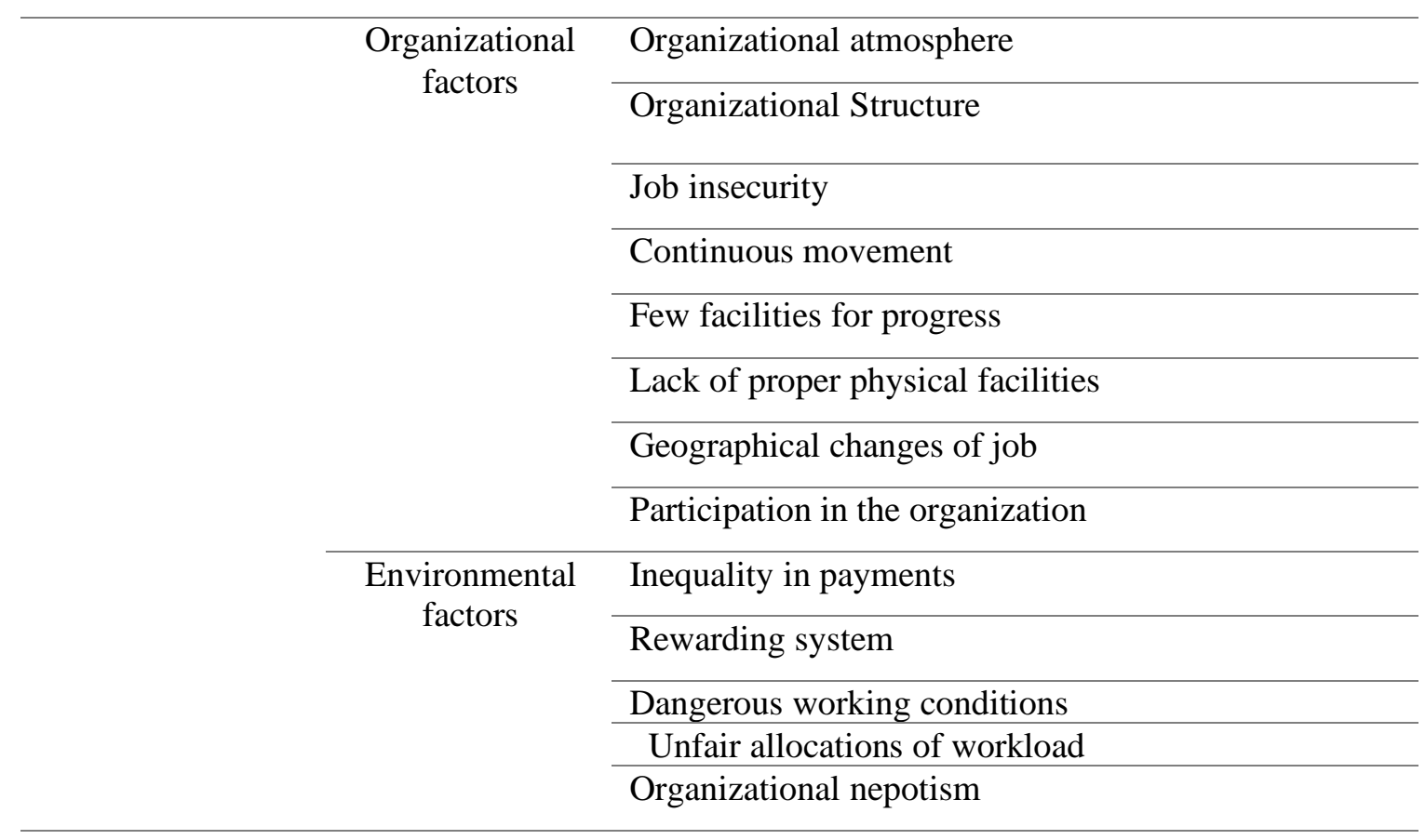

In the second step of Delphi method, first, 24 indicators of factors related to employee stress are screened to select the criteria that are more important and appropriate. Then, by the field experts who were 15 people in the selected sample and were familiar with all subindicators, according to the Delphi method, each criterion was examined based on the purpose. Delphi method was used for the initial screening of the identified criteria (Table 2). 
Table 2.

Summary of the Results of the Second Step of Delphi Method for Factors of Employees Stress

\begin{tabular}{|c|c|c|c|c|c|c|c|c|c|c|c|c|c|c|c|c|c|}
\hline Components & Subcomponents & & & & & & & & & & & & & & & & \\
\hline & & 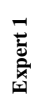 & 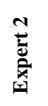 & 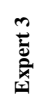 & 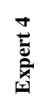 & 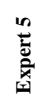 & 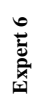 & 兽 & 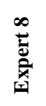 & $\frac{\hat{t}}{\vec{d}}$ & 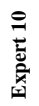 & 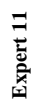 & 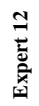 & $\frac{a}{\overrightarrow{0}}$ & 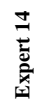 & 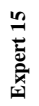 & $\begin{array}{l}3 \\
\frac{3}{0}\end{array}$ \\
\hline \multirow[t]{4}{*}{ Individual factors } & $\begin{array}{l}\text { Difficulties in using } \\
\text { capabilities }\end{array}$ & 4 & 4 & 4 & 5 & 4 & 5 & 4 & 4 & 5 & 4 & 4 & 5 & 5 & 5 & 4 & 404 \\
\hline & $\begin{array}{l}\text { Lack of opportunity to } \\
\text { learn new skills }\end{array}$ & 4 & 4 & 4 & 4 & 5 & 5 & 3 & 4 & 5 & 4 & 5 & 5 & 4 & 5 & 5 & 404 \\
\hline & $\begin{array}{l}\text { Conflict between work } \\
\text { and family }\end{array}$ & 3 & 4 & 5 & 4 & 5 & 5 & 5 & 5 & 5 & 4 & 5 & 5 & 5 & 4 & 5 & 406 \\
\hline & $\begin{array}{l}\text { Conflict in individual } \\
\text { goals }\end{array}$ & 4 & 4 & 3 & 4 & 5 & 4 & 5 & 4 & 5 & 5 & 3 & 5 & 5 & 5 & 5 & 404 \\
\hline \multirow{4}{*}{ Job factors } & Nature of the job & 4 & 5 & 5 & 4 & 5 & 5 & 5 & 4 & 5 & 5 & 4 & 4 & 4 & 5 & 5 & 406 \\
\hline & $\begin{array}{l}\text { Ambiguity and conflict } \\
\text { between roles }\end{array}$ & 4 & 5 & 5 & 5 & 5 & 4 & 5 & 5 & 5 & 5 & 5 & 5 & 5 & 4 & 5 & 408 \\
\hline & $\begin{array}{l}\text { High-volume or low- } \\
\text { volume role and method } \\
\text { of work }\end{array}$ & 5 & 4 & 4 & 5 & 5 & 4 & 5 & 3 & 5 & 4 & 5 & 5 & 5 & 5 & 4 & 405 \\
\hline & Job harassment & 5 & 5 & 5 & 5 & 5 & 3 & 4 & 4 & 5 & 5 & 5 & 5 & 5 & 5 & 4 & 407 \\
\hline \multirow{3}{*}{$\begin{array}{l}\text { Management } \\
\text { factors }\end{array}$} & Management power & 4 & 5 & 4 & 5 & 5 & 4 & 4 & 5 & 4 & 4 & 5 & 5 & 5 & 5 & 5 & 406 \\
\hline & $\begin{array}{l}\text { Personality and man- } \\
\text { agement style }\end{array}$ & 4 & 5 & 4 & 5 & 3 & 4 & 4 & 5 & 4 & 4 & 5 & 5 & 5 & 5 & 5 & 405 \\
\hline & $\begin{array}{l}\text { Management planning } \\
\text { and organization }\end{array}$ & 5 & 5 & 5 & 5 & 5 & 5 & 4 & 5 & 5 & 5 & 5 & 5 & 5 & 5 & 4 & 409 \\
\hline \multirow{13}{*}{$\begin{array}{l}\text { Organizational } \\
\text { factors }\end{array}$} & $\begin{array}{l}\text { Organizational atmos- } \\
\text { phere }\end{array}$ & 4 & 5 & 3 & 5 & 4 & 4 & 4 & 5 & 5 & 5 & 5 & 4 & 5 & 5 & 5 & 405 \\
\hline & $\begin{array}{l}\text { Organizational Struc- } \\
\text { ture }\end{array}$ & 4 & 4 & 5 & 5 & 5 & 4 & 4 & 5 & 5 & 4 & 5 & 4 & 4 & 5 & 5 & 405 \\
\hline & Job insecurity & 5 & 4 & 5 & 4 & 5 & 5 & 5 & 4 & 5 & 5 & 5 & 4 & 5 & 4 & 4 & 406 \\
\hline & Continuous movement & 5 & 4 & 5 & 4 & 4 & 5 & 5 & 4 & 5 & 5 & 5 & 4 & 4 & 4 & 4 & 405 \\
\hline & $\begin{array}{c}\text { Few facilities for } \\
\text { progress }\end{array}$ & 4 & 5 & 5 & 4 & 5 & 5 & 5 & 5 & 5 & 5 & 5 & 5 & 4 & 4 & 4 & 407 \\
\hline & $\begin{array}{l}\text { Lack of proper physical } \\
\text { facilities }\end{array}$ & 5 & 4 & 4 & 4 & 4 & 5 & 5 & 3 & 4 & 5 & 4 & 5 & 5 & 4 & 4 & 403 \\
\hline & $\begin{array}{l}\text { Geographical changes } \\
\text { of job }\end{array}$ & 5 & 3 & 4 & 5 & 4 & 5 & 5 & 5 & 5 & 5 & 4 & 5 & 5 & 4 & 5 & 406 \\
\hline & $\begin{array}{l}\text { Participation in the } \\
\text { organization }\end{array}$ & 4 & 4 & 4 & 3 & 4 & 5 & 4 & 5 & 4 & 5 & 5 & 3 & 5 & 4 & 3 & 401 \\
\hline & Inequality in payments & 4 & 4 & 5 & 5 & 4 & 5 & 5 & 5 & 4 & 5 & 5 & 4 & 4 & 5 & 5 & 4.6 \\
\hline & Rewarding system & 4 & 4 & 5 & 5 & 5 & 5 & 4 & 5 & 5 & 5 & 5 & 5 & 5 & 5 & 5 & 4.8 \\
\hline & $\begin{array}{c}\text { Dangerous working } \\
\text { conditions }\end{array}$ & 4 & 5 & 4 & 4 & 5 & 5 & 4 & 5 & 3 & 5 & 4 & 5 & 5 & 4 & 4 & 4.4 \\
\hline & $\begin{array}{l}\text { Unfair allocations of } \\
\text { workload }\end{array}$ & 4 & 5 & 5 & 5 & 5 & 5 & 3 & 4 & 4 & 5 & 5 & 5 & 5 & 5 & 5 & 4.7 \\
\hline & $\begin{array}{c}\text { Organizational nepo- } \\
\text { tism }\end{array}$ & 4 & 4 & 5 & 4 & 5 & 5 & 4 & 4 & 5 & 4 & 4 & 5 & 5 & 5 & 4 & 4.5 \\
\hline
\end{tabular}


The Delphi method is continued in two steps and is stopped in the second step after reaching a final agreement. Finally, the remaining 24 indicators in the second round have all scored above 3 again. Therefore, the Delphi method has been stopped and the indicators of identified factors related to the stress of employees have been used for the final analysis

The Relationship between the Components of the Stress-related Factors and Stress Management The final structural equation model has been used to measure the relationship between the components of stress-related factors and stress management. The final model is presented in (Figure $1)$.

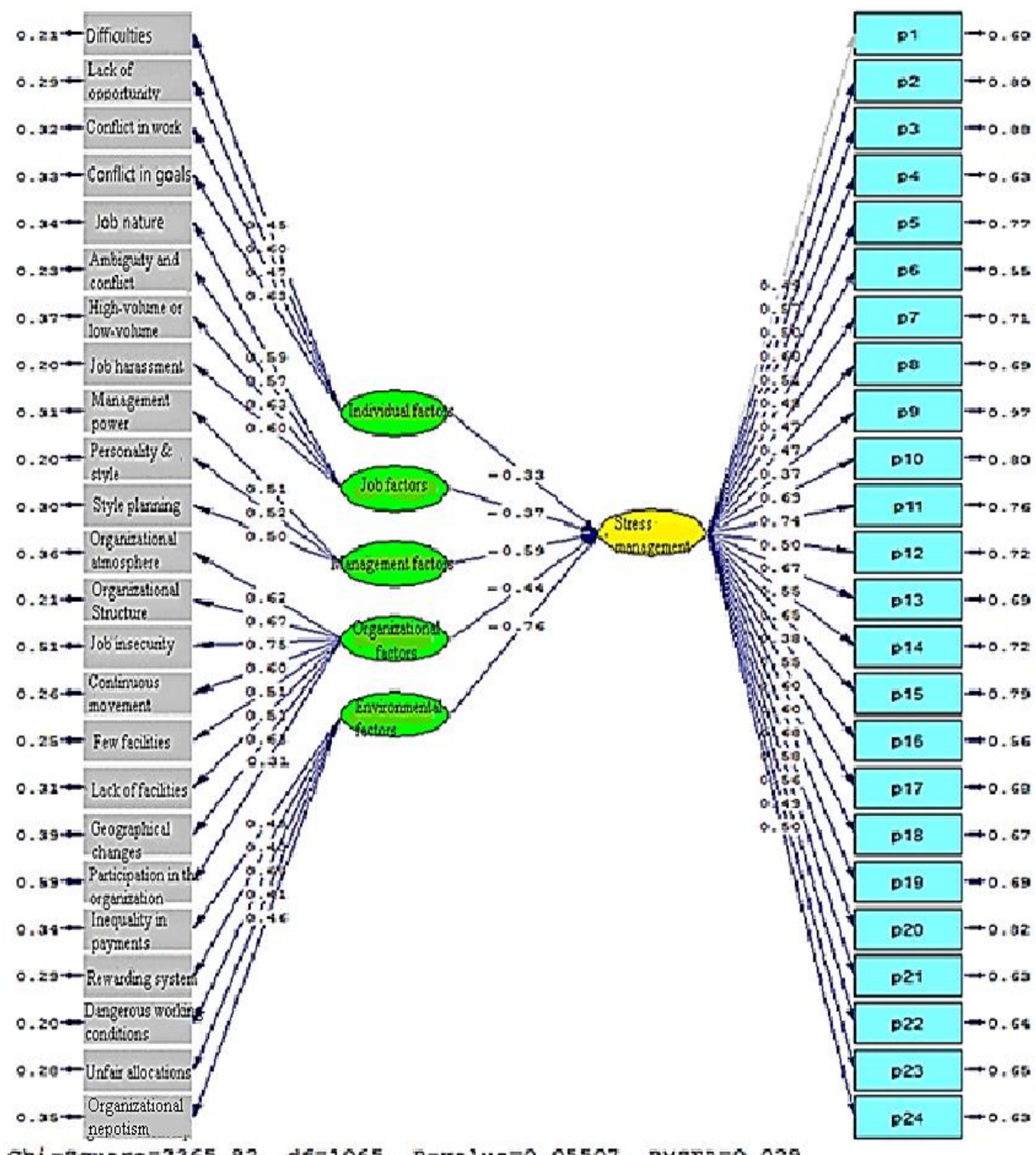

Figure 1. Results of Confirmation of the Final model of the Relationship between Components of Stress-related Factors and Stress Management

The results of measuring the significance of the model data are also presented in (Figure 2). 


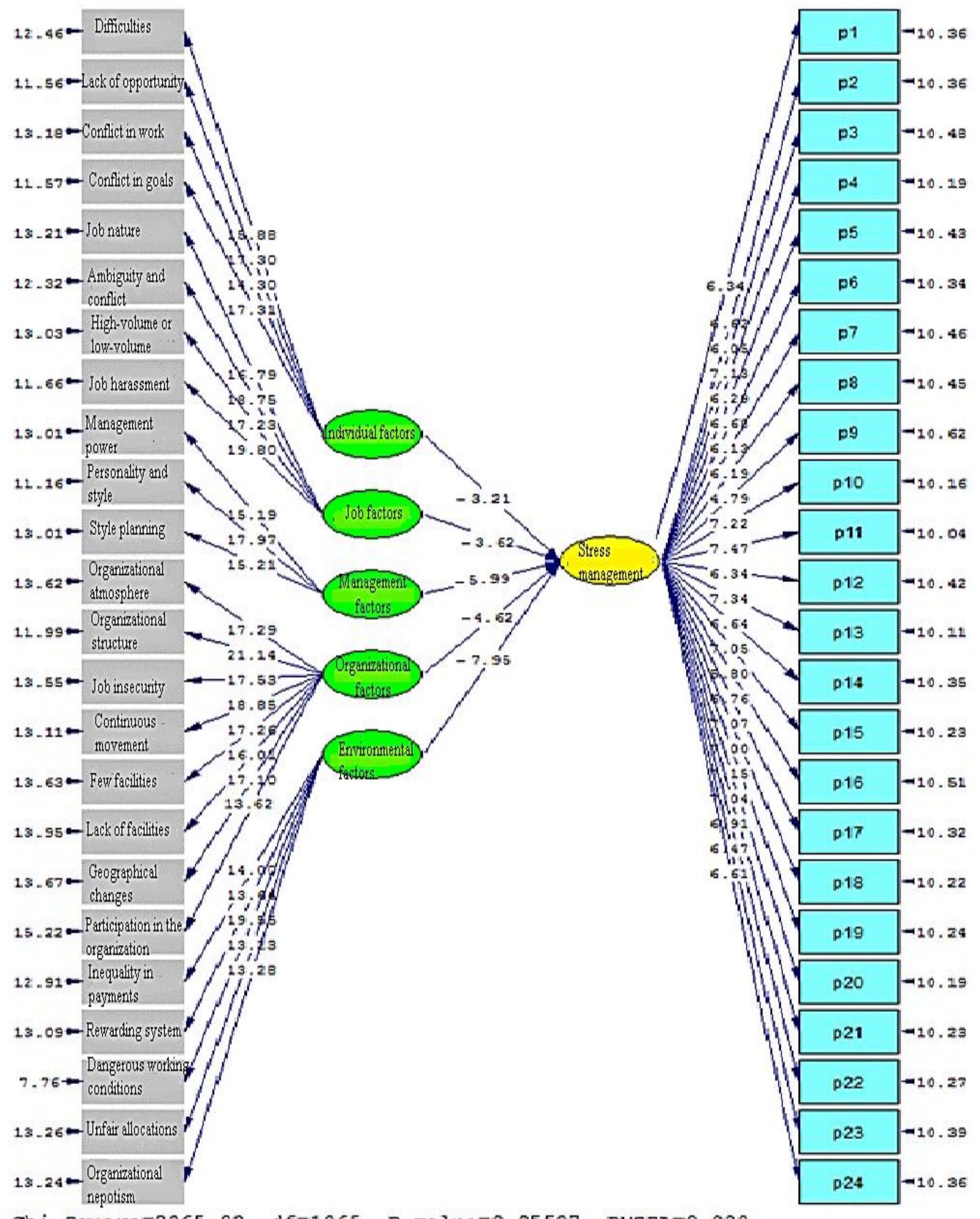

Figure 2. T-Value Statistics of the Results of Confirming the Final Model of the Relationship between Stress-related Factors and Stress Management

Hypothesis Test 1: There is a significant relationship between individual factors of stress and stress management of insurance employees of the Social Security Organization of Iran.

Based on figures 1 and 2, the relationship between the variables of individual stressors and stress management has been calculated to be -0.33 , which shows that the correlation is strong and desirable and is inversed. The t-test of the test is -3.21 which is greater than the critical value of $t$ at an error level of 5\%, i.e. -1.96 and shows that the observed correlation is significant. Therefore, it can be said that there is a significant and inverse relationship between individual factors of stress and stress management of insurance employees of the Social Security Organization of Iran. 
Hypothesis Test 2: There is a significant relationship between job factors of stress and stress management of insurance employees of the Social Security Organization of Iran.

Based on Figures 1 and 2, the relationship between the job variables of stress and stress management has been calculated to be -0.37 , which shows that the correlation is strong and desirable and inverse. The t-test statistic is 3.62 , which is greater than the critical value of $t$ at an error level of $5 \%$, i.e. -1.96 , and shows that the observed correlation is significant. Therefore, it can be said that there is a significant and inverse relationship between job factors of stress and stress management of insurance employees of the Social Security Organization of Iran.

Hypothesis Test 3: There is a significant relationship between stress management factors and stress management of insurance staff of Iran Social Security Organization.

Based on figures 1 and 2, the strength of the relationship between the variables of stress management factors and stress management has been calculated to be -0.59 , which shows that the correlation is strong and desirable and inverse. The t-test statistic is 5.99, which is greater than the critical value of $t$ at an error level of 5\%, i.e. -1.96 , and shows that the observed correlation is significant. Therefore, it can be said that there is a significant and inverse relationship between stress management factors and stress management of insurance employees of the Social Security Organization of Iran.

Hypothesis Test 4: There is a significant relationship between organizational factors of stress and stress management of insurance employees of the Social Security Organization of Iran.

Based on figures 1 and 2, the strength of the relationship between the variables of organizational stress factors and stress management has been calculated to be -0.44 , which shows that the correlation is strong and desirable and inverse. The t-test statistic is 4.62 , which is greater than the critical value of $t$ at an error level of 5\%, i.e. -1.96 , and shows that the observed correlation is significant. Therefore, it can be said that there is a significant and inverse relationship between organizational factors of stress and stress management of insurance employees of the Social Security Organization of Iran.

Hypothesis test 5: There is a significant relationship between environmental factors of stress and stress management of insurance employees of the Social Security Organization of Iran.

Based on figures 1 and 2, the strength of the relationship between environmental variables of stress and stress management has been calculated to be -0.76 , which shows that the correlation is strong and desirable and inverse. The t-test statistic is 7.95 , which is greater than the critical value of $t$ at an error level of 5\%, i.e. -1.96 , and shows that the observed correlation is significant. Therefore, it can be said that there is a significant and inverse relationship between environmental factors of stress and stress management of insurance employees of the Social Security Organization of Iran.

The output of LISREL software indicates the appropriateness of the proposed research model, so that the root mean square error of the approximation (RMSEA) is 0.029 , the normalized chi-square value (CMIN / DF) is 1.891, and the value of the goodness of fit Index (GFI) is equal to 0.97. Other indicators for fitting the proposed research model are given in (Table 3). 
Table 3.

Fit Indicators of the Main Research Model

\begin{tabular}{ccc}
\hline Indicator & Reported value & Acceptable value \\
RMSEA & 0.029 & $\leq 1$ \\
CMIN/DF & 2.221 & $\leq 3$ \\
GFI & 0.97 & $\geq 0.9$ \\
\hline AGFI & 0.96 & $\geq 0.9$ \\
\hline CFI & 0.98 & $\geq 0.9$ \\
\hline NFI & 0.96 & $\geq 0.9$ \\
\hline TLI & 0.97 & $\geq 0.9$ \\
\hline IFI & 0.98 & $\geq 0.9$ \\
\hline
\end{tabular}

\section{Discussion}

Based on the results, it was found that the correlation and strength of the relationship between the two variables of individual factors of stress and stress management of insurance employees of the Social Security Organization of Iran is desirable and these results are in consistent with (Deft, 2019) findings that showed that there was a significant relationship between stress and organizational spirituality and general health. In addition, the correlation coefficient between organizational spirituality and general health was 0.58 and psychological stress was 0.44 . This means that as organizational spirituality increases, so does public health and the stress will be reduced. These results are in consistent with the findings of (Smith, 2018) who showed that stress management skills significantly reduce employee job stress. Stress is the inevitable result of a person's personal and work life. However, stress should not be considered the inevitable result of stressful events. In fact, good management of stress can improve a person's health and performance. Managers need to learn how to create a healthy stress for employees to facilitate their performance.

Based on the obtained results, it was found that the correlation and strength of the relationship between the two variables of occupational factors of stress with stress management of insurance employees of the Social Security Organization of Iran is desirable and these results are in consistent with the findings of (Kay \& Moncarz, 2007). They showed that the psychological pressure of managers in managerial positions depends on factors such as financial management knowledge, personal relationships, communication, leadership, human resource management, job satisfaction, individual and organizational factors as well as environmental and technological factors and other aspects of job position (Kay \& Moncarz, 2007). (Shadmehr et al., 2020) also showed that out of the total sample, 87 patients were with Covid-19 with a mean age of 59/34 years. There is a significant positive correlation between the levels of perceived stress with all health subscales at the level of 0.01 . According to the value obtained from the multiple correlation coefficient (R2), perceived stress can predict (0.425) health. Also, the value obtained from the coefficient $(\beta)$ of perceived stress $(0.369)$ has an effect on health. The development of individual factors and new technologies create demands and stress on employees. Therefore, managers must help employees to adapt to new technologies by ensuring that human dimensions are observed in design and establishment. 
Based on the results, it was found that the correlation and strength of the relationship between the two variables of stress management factors with stress management of insurance staff of the Social Security Organization of Iran is desirable and these results are in consistent with the findings of (Zeinali et al., 2019) who showed that there is a significant relationship between factors related to employees' deviant behaviors (ethical atmosphere and occupational stress) and employees' deviant behaviors with regard to the moderating role of oppressive leadership style of industrial managers.

Immoral and deviant behaviors are also a serious problem for organizations and impose large costs on the organization annually. For this purpose, it is very important for the survival of organizations to identify these behaviors and factors affecting them and to take appropriate measures to reduce them (Zeinali et al., 2019).

(Kouhzadi Foad \& Yousef Eghbalyar, 2019) showed that based on research hypotheses, there is a significant relationship between organizational commitment and its dimensions with job stress and therefore it can be said that the emphasis on organizational commitment in private banks, while preparing an environment full of mental health can reduce job stress in employees. Therefore, more attention to organizational commitment in employees is necessary and improves customer service. Therefore, more attention to organizational commitment in employees is necessary and improves customer service. Some organizations do not have much stress and have healthy work environments, while the stressful environments of some other organizations can endanger the health of employees.

Based on the obtained results, it was found that the correlation and strength of the relationship between the two variables of organizational factors of stress and stress management of insurance employees of the Social Security Organization of Iran is desirable. These results of (Soltani \& Soudbakhsh, 2018) showed self-esteem, the moderating role of "Smart PLS" and "SPSS" impacts on the organizational commitment and job stress on employees' job performance in Isfahan General Directorate of Standards. Also, organizational commitment has a positive and significant effect and job stress has a negative and significant effect on job performance. (Rahimi et al., 2016) showed that there is a significant relationship between stress caused by work, health and personal life and inflammatory bowel disease in adults. It is possible for managers to reduce their stress by motivating employees. Although motivation may not occur directly in employees, it is possible to motivate employees by providing a suitable environment, and this is easier and more fruitful for managers.

Based on the results, it was found that the correlation and strength of the relationship between the two environmental variables of psychological stress and stress management of insurance employees of the Social Security Organization of Iran is desirable. These results are in consistent with the results of (Seyedesmaeili Ghomi et al., 2015). They showed that the research hypothesis on the effect of mindfulness-based stress reduction training on the stress of mothers of mentally retarded children has been confirmed and the mothers in the experimental group compared to the mothers in the control group in the post-test had significantly less stress. Therefore, it can be concluded that mindfulness-based stress reduction training has a significant effect on reducing the stress of mothers of mentally retarded children (Seyedesmaeili Ghomi et al., 2015) and the results are in line with the findings of (Arshadi et al., 2015) who showed inhibitory stressors to quit their jobs and anxiety and the negative effect of these stressors on mental health. In addition, it was shown that anxiety has a direct positive effect on intention to leave the job and a direct negative effect on mental health, organizational civic behaviors, task performance and organizational self-esteem. The results of indirect relationships also confirmed the effect of inhibitory phases on mental health, organizational civic behaviors, task performance, and organizational-centered self-esteem through anxiety (Arshadi et al., 2015). 


\section{Conclusion}

Leadership in the organization reflects the executive and senior management style of the organization. Some senior executives in their management style create a culture that dominates the organization and causes fear, panic, anxiety and tension among employees. In a hierarchical system, if the type of behavior or style of the manager adapts to the tastes of employees, less pressure is put on them, but if the expectations of employees are not consistent with the style of the manager, employees must bear the stress of incompatibility. This relationship is also true in the style or manner in which high-level managers treat lower-level managers. Each factor of stress alone is not very important, but stress is a phenomenon that has the property of increasing, and each new factor, together with the underlying factor, increases the level of stress. The role of a factor is like a straw that broke the camel's back. To assess the level of stress of each person, it is necessary to calculate the sum of the stress resulting from opportunities, constraints and demands of him.

\section{References}

Ranjbar M. \& Mantegh A. (2018), The Effect of Emotional Intelligence and Job Stress on Organizational Commitment of Shiraz Education Managers in the academic year 2017. Quarterly Journal of Strategic Studies in Humanities and Islamic Sciences, 22(4): 2748.

Maier C. \& Laumer S. \& Eckhardt A. \& Weitzel T. (2013), Analyzing the impact of HRIS implementations on HR personnel's job satisfaction and turnover intention, The Journal of Strategic Information Systems, 22(3): 193-207

Qarakhani D. \& Zafaranchi A. (2018), The Effect of Burnout on Employees' Intention to Leave the Service by Considering the Mediating Role of Job Satisfaction. Health Quarterly, 10(1): 109-117.

Nguyen V. (2015), Job characteristics, job embeddedness, and turnover intention: The case of Vietnam. Journal of International \& Interdisciplinary Business Research, 2(5): 97109.

Llopis O. \& Foss N. (2016), Understanding the climate-knowledge sharing relation: The moderating roles of intrinsic motivation and job autonomy, European Management Journal, 34(2): 135-144.

Imani K. \& Mokhtari A. (2018), Investigating the Effects of Job Stress among Flight Care Staff, Health Quarterly, 4(9): 129-140.

Talebi N. (2018), The Effectiveness of Aerobic Exercise Interventions and Stress Coping Skills Training on Reducing Job Stress in Firefighters, Journal of Clinical Psychology and Personality, 3(3): 11-18.

Afshani A. \& Jahanbakhsh Ganjeh S. \& Jahanbakhsh Ganjeh S. (2017), Investigating the Rate of Burnout and related Factors among the Employees of Kohgiluyeh and Boyer-Ahmad Social Security Organization, Journal of Knowledge and Research in Applied Psychology, 18(2): 72-81.

Zamanian A. \& Pakdel Z. (2015), Investigating the Relationship between Organizational Commitment and Job Burnout among Social Security Organization Employees. World Conference on Management, Accounting Economics and Humanities at the beginning of the third millennium, Shiraz, research of Green Industry Idea Market Company, 19(4): 185196.

Deft F. (2019), The Relationship between Organizational Spirituality and Public Health and Stress of Xi Soren Municipality Employees, Journal of Management and Enterprise Development, 5(1): 77-101.

Smith N. (2018), The effectiveness of coping skills training on reducing staff stress, The Conference on Mental Health, 5(1): 77-101.

Kay C. \& Moncarz E. (2007), Managers' stress in managerial positions". International Journal of Hospitality Management, 26(3): 33-48. 
Shadmehr M. \& Ramak N. \& Sangani A. (2020), The Role of Perceived Stress in the Health of People Suspected of Having Covid-19, Journal of Military Medicine, 22(2): 115-121.

Zeinali S. \& Manzaritavakoli A. \& Salajegheh S. (2019), The Relationship Between Ethical Climate and Job Stress with Employees' Deviant Behaviors: The Moderating Role of Oppressive Leadership Style, Quarterly Journal of Ethics in Science and Technology, 14(3): 116-124.

Kouhzadi Foad M. \& Yousef Eghbalyar A. (2019). Investigating the Relationship between Organizational Commitment and Mental Health and Job Stress among Private Bank Employees, Quarterly Journal of Modern Banking Studies, 2(3): 221-232.

Soltani H. \& Soudbakhsh S. (2018), The Relationship Between Workplace Stress and Business Agility on Organizational Effectiveness. Quarterly Journal of Human Resource Management and Support Development, 50(5): 43-62.

Rahimi S. \& Vahedi H. \& Gachkar L. \& Mohtahedi H. \& Sehfollahi M. (2016). Investigating the Relationship Between Work-Related Stress, Personal Health and Life, and Inflammatory Bowel Disease in Adults. Journal of Alborz University of Medical Sciences, 5(2): 67-72.

Seyedesmaeili Ghomi N. \& Kazemi F. \& Pezeshk S. (2015), The Effect of Mindfulness-Based Stress Reduction Training on the Level of Stress of Mothers Having Intellectual Disability Children. Quarterly Journal of Psychology of Exceptional People, 17(5): 133-148.

Arshadi N. \& Danesh F. \& Neisi A. (2015), Designing and Testing a Model of Some Consequences of Challenging and Deterrent Pressures in the Staff of the National Iranian Steel Industrial Group. Quarterly Journal of Job and Organizational Counseling, 22(7): 33-52. 